\title{
Metisiline Dirençli Stafilokoklarda Azalmış Vankomisin Duyarlılığının Araştırılması
}

\author{
Fatma AVCIOĞLU 國, C. Elif ÖZTÜRK ${ }^{2}{ }^{2}$, İdris ŞAHIN ${ }^{2}{ }^{2}$, Şükrü ÖKSÜZ 间 $^{2}$, \\ Arif KIZILIRMAK $\mathbb{0}^{2}$, Nida AKAR 间 $^{3}$
}

\section{ÖZ}

Amaç: Son yıllarda metisilin dirençli stafilokoklarda glikopeptid grubu antibiyotiklere karşı azalmış duyarlılıktan söz edilmektedir. Hastanemiz mikrobiyoloji laboratuvarına gönderilen çeşitli klinik örneklerde vankomisine dirençli (VRS), azalmış duyarlı (VIS) ve heterojen dirençli (hVIS) stafilokok suşlarını araştırmayı amaçladık.

Gereç ve Yöntemler: Toplam 341 stafilokok suşu incelemeye alındı. S. aureus izolatlarında metisilin direncini saptamada, oksasilin agar tarama testi kullanıldı. Koagülaz negatif stafilokok izolatlarında metisilin direncinin saptanmasında oksasilin disk difüzyon testine göre duyarlılı̆̆ı ve özgüllüğ̈̈ daha yüksek olan sefoksitin disk difüzyon $(30 \mu \mathrm{g})$ yöntemi kullanıldı. Metisiline karşı dirençli bulunan stafilokoklarda vankomisin direncini saptamada; vankomisin agar tarama, standart E-test, Makro E-test ve popülasyon analiz profili yöntemleri kullanıldı.

Bulgular: S. aureus izolatlarının 115 'i $(\% 54,2)$ metisilin dirençli S. aureus (MRSA), koagülaz negatif stafilokok izolatlarının 66'sı (\%51,2) metisilin dirençli koagülaz negatif stafilokok (MRKNS) olarak bulundu. 181 metisilin dirençli stafilokok suşunun vankomisin agar tarama yöntemine göre ilk 24 saatte sadece ikisinde kuşkulu vankomisine duyarlılığ azalmış stafilokok suşu (VIS) üremesi saptandı. Üreme saptanan suşların her ikisi de S. aureus idi. Metisilin dirençli S. aureus suşları standart E Test ve Makro E Test incelemelerinde vankomisine duyarlı olarak bulundu. PAP yöntemi ile hiçbir suşta vankomisin direnci saptanmadı.

Sonuç: Çalışmamıza göre laboratuvarımızda izole edilen metisilin dirençli stafilokoklarda vankomisine karşı direnç (VRS), azalmış duyarlılık (VIS) ve heterojen direnç (hVIS) saptanmamıştır. Bu seçkin antibiyotiğin özenli kullanılmasının, gerek tedavi öncesi, gerekse tedavi sırasında hastaların mikrobiyolojik yönden yakın izleminin önemli ve gerekli olduğu düşünüldü.

Anahtar Kelimeler: Staphylococcus aureus; direnç; vankomisin.

\section{Investigation of Decreased Vancomycin Susceptibility in Methicillin Resistant Staphylococci}

\begin{abstract}
Aim: In recent years, decreased susceptibility to glycopeptide group antibiotics has been reported in methicillin resistant staphylococci. We aimed to investigate vancomycin resistant (VRS), vancomycin intermediate (VIS) and heterogeneous resistant (hVIS) staphylococci strains in various clinical specimens sent to our hospital microbiology laboratory.

Material and Methods: A total of 341 staphylococcus strains were examined. Oxacillin agar screening test was used to determine methicillin resistance in $S$. aureus isolates. In the determination of methicillin resistance in coagulase negative staphylococci isolates, disc diffusion $(30 \mu \mathrm{g})$ method with higher sensitivity and specificity than oxacilin disc diffusion test was used. To determine vancomycin resistance in methicillin-resistant staphylococci; vancomycin agar screening, Standard E-test, Macro E-test and Population analysis profile methods were used.

Results: 115 (54.2\%) of S. aureus isolates were methicillin resistant S. aureus (MRSA), 66 (51.2\%) of coagulase negative staphylococci isolates were found to be methicillin resistant coagulase negative staphylococci (MRCNS). Of the 181 methicillin-resistant staphylococcus strains, only two [strains of suspected vancomycin-susceptible staphylococcus strain (VIS)] were detected in the first 24 hours according to vancomycin agar screening method. Both strains were $S$. aureus. Methicillin-resistant $S$. aureus strains were found to be susceptible to vancomycin in standard
\end{abstract}

1 Bolu Abant İzzet Baysal Üniversitesi, Tıp Fakültesi, Tıbbi Mikrobiyoloji AD, Bolu, Türkiye

2 Düzce Üniversitesi, Tıp Fakültesi, Tıbbi Mikrobiyoloji AD, Düzce, Türkiye

3 Hacettepe Üniversitesi, Tıp Fakültesi, Tıbbi Mikrobiyoloji AD, Mikoloji Laboratuvarı, Ankara, Türkiye

Sorumlu Yazar / Corresponding Author: Fatma AVCIOĞLU, e-mail: fatmaavcioglu@yahoo.com.tr

Geliş Tarihi / Received: 14.06.2019, Kabul Tarihi / Accepted: 31.12.2019 
E Test and Macro E Test examinations. No vancomycin resistance was detected by PAP method.

Conclusion: According to our study, vancomycin resistance (VRS), vancomycin intermediate (VIS) and heterogeneous resistance (hVIS) were not detected in methicillin resistant staphylococci isolated in our laboratory. Careful use of this selective antibiotic and microbiological follow-up of the patients before and during treatment were considered important and necessary.

Keywords: Staphylococcus aureus; resistance; vancomycin.

\section{GIRIS}

Genel olarak mikroorganizmalarda antibiyotiklere karşı hızla gelişen direnç mekanizmalarından dolayı bakteriyel enfeksiyonların tedavisinde ciddi sorunlar yaşanmakta ve bu da yeni antibiyotiklere duyulan ihtiyacı arttırmaktadır. Gram pozitif koklar, özellikle de metisiline dirençli $S$. aureus (MRSA) türleri hastane kaynaklı enfeksiyonlarda önemli yer tutmaktadır $(1,2)$. Son yıllarda, MRSA enfeksiyonlarının epidemiyolojisinde önemli değişiklikler meydana gelmiştir. Bunlardan birincisi $S$. aureus izolatlarında görülen metisilin direnç oranlarındaki artıştır (2). İkinci önemli değişiklik, bazı merkezlerde MRSA izolatlarında görülen vankomisin duyarlılığındaki azalmadır. Bu izolatların vankomisin MİK değerleri $\leq 2$ $\mu \mathrm{g} / \mathrm{ml}$ olmak üzere duyarlı sınırlarında olmasına rağmen, vankomisin tedavisi ile başarısız klinik sonuçlar elde edilmektedir. Üçüncüsü, MRSA izolatları arasında vankomisine orta düzeyde duyarlı S. aureus (VISA), heterojen VISA (hVISA) ve vankomisine dirençli $S$. aureus (VRSA)'ların ortaya çıkmasıdır. Dördüncü önemli değişiklik ise MRSA sorununun sadece hastanelerde sınırlı kalmayıp toplumda da görülmeye başlamasıdır (3). $\mathrm{Bu}$ sebeplerden dolayı çalışmamızda Ocak 2010-Kasım 2013 tarihleri arasında hastanemiz mikrobiyoloji laboratuvarına gönderilen çeşitli klinik örneklerden izole edilen stafilokok suşlarında vankomisin direncini (VIS, hVIS, VRS varlığını) araştırmayı amaçladık.

\section{GEREÇ VE YÖNTEMLER}

\section{Örneklem Grubunun Oluşturulması ve Antibiyotik Duyarlılık Testleri}

2012/257 nolu etik kurul onayı ile gerçekleştirilen bu çalışmada Ocak 2010-Kasım 2013 tarihleri arasında mikrobiyoloji laboratuvarına gönderilen çeşitli klinik örneklerden (idrar, balgam, kan, yara sürüntüsü, bronş lavaj sıvısı, katater ucu... vb.) izole edilen toplam 341 stafilokok suşu incelemeye alındı. İzolatların tanımlanmasında konvansiyonel laboratuvar yöntemleri ve otomatize sistemler kullanıldı. Koagülaz negatif stafilokokların (KNS) tiplendirilmesinde VITEK ${ }^{\circledR} \quad 2$ otomatize sistem (Biomeriux, Fransa) kullanıldı.

Metisilin direncini belirlemede PCR (Polimeraz Zincir Reaksiyonu) ile mecA geninin tespiti altın standart olarak kabul edilmektedir. Moleküler tekniklerin pahalı ve zaman alıcı olması sebebiyle rutin olarak kullanma imkânı olmadığından, metisilin direncini gösteren fenotipik yöntemler çalışmamızda kullanılmıştır. $S$. aureus izolatlarında metisilin direncini saptamada, Clinical Laboratory Standards Institute (CLSI), 2010 önerileri doğrultusunda oksasilin agar tarama testi kullanıldı. Kontrol suşu olarak S. aureus ATCC 29213 ve ATCC 25923 kullanıld (4). KNS'lerde metisilin direncinin saptanmasında oksasilin disk difüzyon testine göre duyarlılığı ve özgüllüğü daha yüksek olan sefoksitin disk difüzyon $(30 \mu \mathrm{g})$ yöntemi kullanıldı (5). CLSI tarafından belirlenen direnç sınır değerlerine göre inhibisyon zon çap $1 \leq 21 \mathrm{~mm}$ olan izolatlar dirençli, $\geq 22$ $\mathrm{mm}$ olan izolatlar ise duyarlı olarak kabul edildi (6-8). Kontrol suşu olarak S. aureus ATCC 25923 ve S. aureus ATCC 43300 kullanıldı. Çalışma 2015, European Committee of Antimicrobial Susceptibility Testing (EUCAST) geçiş yılı, öncesinde yapıldığı için stafilokokların metisilin direncini tespit etmede ve yorumlamada CLSI kriterleri kullanıldı.

\section{Vankomisin direncinin belirlenmesi ve yorumu}

Metisiline dirençli bulunan stafilokok suşları $6 \mu \mathrm{g} / \mathrm{mL}$ vankomisin içeren beyin kalp infüzyon agar (BKİA) besiyerine ekildi. Tarama besiyerlerinde 24. saatte üreyen bakteriler, kuşkulu vankomisine duyarlılığı azalmış stafilokok suşu (VIS), 48. saatte üreyen bakteriler ise kuşkulu heterojen vankomisine duyarlılığı azalmış stafilokok suşu (hVIS) olarak kabul edildi. Üreme göstermeyen izolatlar ise vankomisine duyarlı olarak değerlendirildi (9) .

Tarama besiyerinde üreyen stafilokok suşlarına bir ileri basamak olarak standart E-test, Makro E-test ve altın standart yöntem olarak kabul edilen popülasyon analiz profili (PAP) yöntemi uyguland.

Standart E-test yönteminde, vankomisin MIK değerleri $S$. aureus için $\leq 2 \mu \mathrm{g} / \mathrm{ml}$ duyarlı, 4-8 $\mu \mathrm{g} / \mathrm{ml}$ orta duyarlı, $\geq$ $16 \mu \mathrm{g} / \mathrm{ml}$ dirençli; KNS için $\leq 4 \mu \mathrm{g} / \mathrm{ml}$ duyarlı, 8-16 $\mu \mathrm{g} / \mathrm{ml}$ orta duyarlı, $\geq 32 \mu \mathrm{g} / \mathrm{ml}$ dirençli kabul edildi. Kontrol suşu olarak S. aureus ATCC 29213 kullanıldı (9). Makro E-test yönteminde, vankomisin MİK değerleri $\geq 8 \mu \mathrm{g} / \mathrm{ml}$ olan izolatlar VIS/hVIS olarak yorumland1.

PAP-AUC yönteminde, 0,5 McFarland ve bunun $10 \mathrm{~kat}$ seri dilüsyonlarından 50'şer $\mu$ l alınarak (toplam altı kez dilüe edilerek) her bir süspansiyondan, 1, 2, 3, 4, 5, 6, 7, $8,9,10 \mu \mathrm{g} / \mathrm{ml}$ vankomisin içeren BKİA besiyerlerinden her birine ayrı ayrı ekim yapıldı. $35^{\circ} \mathrm{C}$ 'de 48 saat inkübe edildikten sonra, koloni sayımları gerçekleştirildi. Plaklarda her bir konsantrasyonda üreyen kolonilerin sayıları y eksenine, antibiyotik konsantrasyonları ise $\mathrm{x}$ eksenine yerleştirilerek grafikleri çizildi. Her bir suş için eğri altındaki alan (AUC) Microsoft Excel programıla hesaplandı. Elde edilen değer, standart hVISA suşu olan Mu3 için hesaplanan AUC değerine bölünerek bir oran elde edildi. $\mathrm{Bu}$ oran $\leq 0,90$ ise vankomisine duyarl stafilokok, $0,90-1,3$ ise hVIS, $\geq 1,3$ ise VIS olarak değerlendirildi (9). Kontrol suşu olarak Mu3 (hVISA) ve Mu50 (VISA) kullanıldı.

\section{BULGULAR}

Toplam 341 stafilokok etken olarak izole edildi. Bunlardan 212'si (\%62,2) S. aureus, 129'u (\%37,8) KNS idi. KNS suşlarının 41 'i $(\% 31,8)$ S. hominis, 38'i $(\% 29,5)$ S. epidermidis, 28'i (\%21,7) S. haemoliticus ve 22'si (\%17) diğer stafilokok türlerindendi. S. aureus izolatlarının 115'i (\% 54,2) MRSA, 97'si (\%45,8) MSSA olarak saptandı. KNS izolatlarının ise 66's1 $(\% 51,2)$ metisilin dirençli KNS (MRKNS), 63'ü $(\% 48,8)$ metisilin duyarlı KNS (MSKNS) olarak bulundu. Tüm stafilokokların (S. aureus ve KNS) metisilin direnç 
oranları Tablo 1'de gösterildi.

Tablo 1. İncelenen tüm stafilokok suşlarında metisilin direnç oranlarının dağılımı

\begin{tabular}{|c|c|c|}
\hline Izolat tü̈rü & Sayı & \% \\
\hline MRSA & 115 & 33,7 \\
\hline MRKNS & 66 & 19,4 \\
\hline MSSA & 97 & 28,4 \\
\hline MSKNS & 63 & 18,5 \\
\hline Toplam & $\mathbf{3 4 1}$ & $\mathbf{1 0 0 , 0}$ \\
\hline
\end{tabular}

MRSA: Metisilin dirençli Staphylococcus aureus, MRKNS: Metisilin dirençli koagülaz negatif stafilokok, MSSA: Metisilin duyarlı Staphylococcus aureus, MSKNS: Metisilin duyarlı koagülaz negatif stafilokok

Tüm stafilokokların gönderildiği kliniklere ve örnek türlerine göre dağılımları Tablo 2 ve Tablo 3 'te ayrıntılı olarak gösterildi. MRSA ve MRKNS'nin yoğun bakım ünitelerinde; yara, kan ve katater ucu kültür örneklerinde diğer klinikler ve örneklere göre daha fazla ürediği görüldü. MSSA ve MSKNS örnekleri ise acil serviste; kan ve katater ucu kültür örneklerinde daha fazla belirlendi.

Tablo 2. İzolatların kliniklere göre dağılımı ve yüzdesi

\begin{tabular}{|l|c|c|}
\hline Klinik & Sayı & \% \\
\hline Acil Servis & 76 & 22,3 \\
\hline $\begin{array}{l}\text { Beyin ve Sinir } \\
\text { Cerrahisi Kliniği }\end{array}$ & 55 & 16,2 \\
\hline $\begin{array}{l}\text { Çocuk Sağlığı ve } \\
\text { Hastalıkları Kliniği }\end{array}$ & 27 & 7,9 \\
\hline Dermatoloji Kliniği & 18 & 5,3 \\
\hline $\begin{array}{l}\text { Dahili Yoğun } \\
\text { Bakım Servisi }\end{array}$ & 14 & 4,1 \\
\hline $\begin{array}{l}\text { Enfeksiyon } \\
\text { Hastalıkları Kliniği }\end{array}$ & 28 & 8,2 \\
\hline $\begin{array}{l}\text { İç Hastalıkları } \\
\text { Kliniği }\end{array}$ & 22 & 6,5 \\
\hline $\begin{array}{l}\text { Koroner Yoğun } \\
\text { Bakım Ünitesi }\end{array}$ & 13 & 3,8 \\
\hline Nöroloji Servisi & 7 & 2,1 \\
\hline Ortopedi Kliniği & 24 & 7,1 \\
\hline $\begin{array}{l}\text { Pediatri Yoğun } \\
\text { Bakım Servisi }\end{array}$ & 11 & 5,9 \\
\hline $\begin{array}{l}\text { Reanimasyon } \\
\text { Servisi }\end{array}$ & 15 & 3,2 \\
\hline Üroloji Kliniği & 341 & 4,4 \\
\hline Diğerleri & & 3,3 \\
\hline Toplam & 100 \\
\hline
\end{tabular}

Tablo 3. İzolatların örnek türlerine göre dağılımı ve yüzdesi

\begin{tabular}{|l|c|c|}
\hline Örnek Türü & Sayl & \% \\
\hline Kan ve Katater & 152 & 44,6 \\
\hline Yara yeri & 98 & 28,7 \\
\hline İdrar & 52 & 15,2 \\
\hline Balgam ve Trakeal aspirat & 28 & 8,2 \\
\hline Doku & 7 & 2,1 \\
\hline Periton sivisı & 4 & 1,2 \\
\hline Toplam & 341 & 100 \\
\hline
\end{tabular}

Metisilin dirençli stafilokoklarda vankomisin direncini saptamada tarama yöntemi olarak kullanılan vankomisin agar besiyerine ekilen 181 metisilin dirençli stafilokok ( $S$. aureus ve KNS) suşunun ilk 24 saatte sadece ikisinde üreme saptand1. Şekil 1'de üreme görülen koloniler gösterildi. Üreme saptanan suşların her ikisi de S. aureus idi. 48.saatte yeni üreme hiç olmadi. Vankomisinli agar tarama yöntemi sonuçları Tablo 4'te gösterildi.

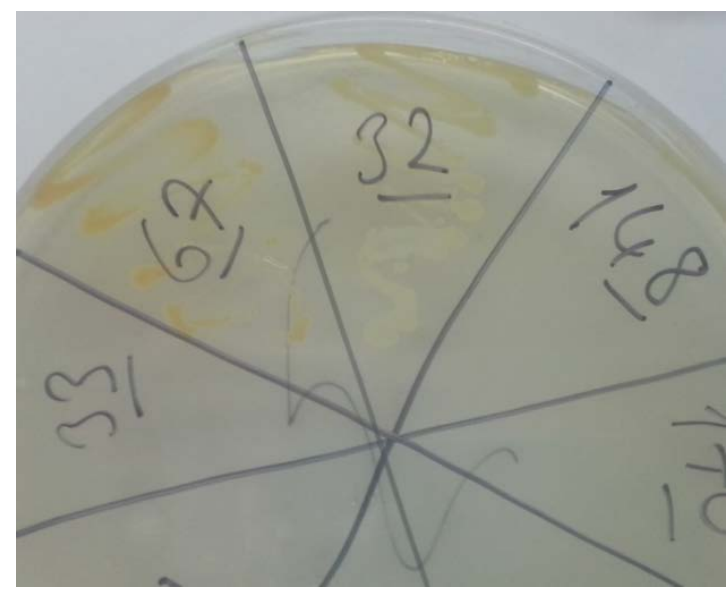

Şekil 1. Vankomisin agarda 24. saatte üreme görülen koloniler

Tablo 4. Vankomisinli agar tarama yöntemi sonuçları

\begin{tabular}{|c|c|c|}
\hline İolat türü & 24. saatte üreme & 48. saatte üreme \\
\hline MRSA & 2 & - \\
\hline MRKNS & - & - \\
\hline Toplam & 2 & 0 \\
\hline
\end{tabular}

Vankomisinli agar tarama yönteminde üreme görülen MRSA suşları 1 ve 2 numaralı izolatlar olarak isimlendirildi. $\mathrm{Bu}$ MRSA suşları standart $\mathrm{E}$ Test ve Makro E Test incelemelerinde vankomisine duyarlı olarak bulundu. Test sonuçları Tablo 5 'te gösterildi.

Tablo 5.1 ve 2 numaralı izolatların standart ve Makro E test sonuçları

\begin{tabular}{|l|c|c|}
\hline Suş numarası & $\begin{array}{c}\text { Standart E test } \\
\text { Sonucu } \\
(\boldsymbol{\mu g} / \mathbf{m l})\end{array}$ & $\begin{array}{c}\text { Makro E test } \\
\text { Sonucu } \\
(\boldsymbol{\mu g} / \mathbf{m l})\end{array}$ \\
\hline 1 Numaralı & 1,5 & 3 \\
\hline 2 Numaralı & 2 & 4 \\
\hline
\end{tabular}

\section{PAP Yöntemi Sonuçları}

Vankomisinli agar tarama yöntemi ile şüpheli bulunan hVIS/VIS suşlarının hiçbirinde PAP yöntemi ile vankomisine direnç saptanmamıştır.

\section{TARTISSMA}

Penisilinin 1928 yılında Alexander Fleming tarafindan bulunması ile stafilokokal enfeksiyonların tedavisinde önemli bir aşama kaydedilmiştir. Stafilokokların penisilinaz üretmesiyle 1944'de penisilin direnci giderek artmış, 1950'li yıllarda penisilinin yanı sıra eritromisin, tetrasiklin, streptomisin gibi diğer antibiyotiklere de direnç gelişmiştir (10). Penisilinaza dirençli penisilinlerin (metisilin), 1960'da kullanıma girmesiyle birlikte stafilokokal enfeksiyonların tedavisinde ikinci önemli aşama kaydedilmiştir. Ancak çok kısa bir süre içerisinde (1961) stafilokoklarda metisilin direnci tanımlanmış ve 1970'li yıllardan itibaren de MRSA suşlarında çoklu antibiyotik direnci problemi ortaya çıkmıştır. Direnç 
probleminin artmasıyla birlikte MRSA tüm dünyada nozokomiyal epidemilere yol açan ciddi bir sağlık sorunu haline gelmiştir (10). Özellikle yoğun bakım ünitelerinde olmak üzere MRSA enfeksiyonları giderek artan oranlarda rapor edilmektedir (1). MRSA bakteriyemisi gibi ciddi klinik tablolarda hastanede yatış süresi belirgin olarak uzamakta ve medikal maliyet oranları daha fazla olmaktadır (11).

Amerika Birleşik Devletleri'nde (ABD) yoğun bakım ünitelerinde $S$. aureus izolatları arasında metisilin direncinin prevalansı \%60’tır (12). Ülkemizde 2003-2004 yıllarında yapılan yayınlar izole edilen $S$. aureus suşlarında \%52 metisilin direnci olduğunu göstermiştir (13). 2008-2009 yıllarında Refik Saydam Hifzıssıhha Merkezi Başkanlığı'nca yayınlanan Ulusal Hastane Enfeksiyonları Sürveyans Ağı (UHESA) raporu özet veri kitapçığında sunulan antimikrobiyal direnç hızlarının persentil dağılımları tablosunda MRSA'un ağırlıklı genel ortalaması 2008 yılında 58,9 olarak, 2009 yılında 58,5 olarak belirtilmiştir. Aynı kitapçık 2010 yılında da yenilenerek sunulmuştur. 2010 yılında ağırlıklı genel ortalama MRSA için $(53,4)$, MRKNS için ise $(73,0)$ olarak gösterilmiştir (14). Çalışmamızda saptadığımız \%54,2 MRSA oran1, Türkiye'den bildirilen UHESA verilerine ve Amerika'dan bildirilen MRSA oranlarına benzer olduğu görülmüştür. Çalışmamızda izole edilen MRSA örneklerinin gönderildiği kliniklere göre dağılımında \%22,6 yoğun bakım ünitelerinde, \%20,9 enfeksiyon hastalıkları kliniğine, \%15,6 nöroşirürji, \%13 ortopedi, \%11,3 dahiliye kliniğine ait olduğu görülmüştür. Bu bölümlerin hastaların uzun süre yatarak yoğun antibiyotik tedavisi aldığı klinikler olduğu dikkat çekmektedir. MRSA'ların örnek türlerine göre dağılımı incelendiğinde \%60'1 yara, \%20'si solunum yolu sekresyonu, \%13’ü idrar, \%3,5’i kan ve kateter olarak bulunmuştur. Buna karşın MRKNS'ların kliniklere göre dağılımı incelendiğinde $\% 25,8$ dahiliye, $\% 22,7$ yoğun bakım ünitesi (YBÜ), \%18,2 acil, \%13,6 pediatri kliniğine ait olduğu; örnek türlerine göre dağılımı incelendiğinde $\% 53$ kan ve kateter, \%25,8 yara, \%18,2 idrar olduğu tespit edilmiştir. Mikrobiyoloji laboratuvarında izole edilen KNS’lerin gerçek etken olup olmadığının belirlenmesinde çok önemli bir rol de klinisyene düşmektedir. İzole edilen her MRKNS'nin etken olamayacağı aşikârdır. Bunların birçoğunun kontaminant bakteriler olabileceği unutulmamalıdır. Çalışmamızda tespit edilen KNS türlerinden çoğunluğunu, S. hominis ve $S$. epidermidis oluşturmuştur. $\mathrm{Bu}$ bakteriler KNS türleri arasında çoğunlukla kontaminant bakteri olarak kabul edildiği için, dahiliye ve YBÜ'den gelen kan ve katater ucu kültür örneklerinin çoğunluğunun kontaminasyon olabileceğini düşündürmüştür.

Günümüzde MRSA enfeksiyonlarının tedavisinde glikopeptid grubu antibiyotikler kullanılmaktadır. Glikopeptid grubu ilaçlar, hücre duvar sentezini inhibe ederek etki gösterirler. Sentezlenmekte olan hücre duvarının bir komponenti olan peptidoglikanın D-alanilD-alanin ucuna bağlanarak transpeptidasyon basamağını inhibe ederler (15). İlk olarak 1958 yılında kullanıma giren ve sadece Gram pozitif bakterilere etkili olan vankomisine karşı uzun yıllar boyunca direnç saptanmamıştır. Ancak 1989 yılında vankomisine dirençli enterokoklar (VRE) görülmeye başlanmış; bunu 1996 yilında VISA ve 2002 yilında da VRSA izolatları izlemiştir (15).

1997 yılında, VISA suşlarının ortaya çıkmasından kısa bir süre sonra Hiramatsu ve arkadaşları, "heterojen VISA (hVISA)" olarak adlandırılan yeni bir vankomisin direnç tipi tanımlamışlar ve "Mu 3" olarak isimlendirmişlerdir (16). $\mathrm{Bu}$ ilk izolattan sonra birçok ülkede değişen oranlarda hVISA izolatları bildirilmiştir (17). CLSI tarafından belirlenen vankomisin direnç sınır değerlerine göre VISA ve VRSA izolatları tanımlanabilirken, hVISA izolatları için bu geçerli değildir. CLSI kriterlerine göre vankomisine duyarlı bulunan (vankomisin MIK değeri $\leq$ $2 \mu \mathrm{g} / \mathrm{ml}$ ) ancak en az $10^{4}-10^{5}$ 'te bir siklıkta olmak üzere, MİK değeri $>2 \mu \mathrm{g} / \mathrm{ml}$ olan subpopülasyon içeren suşlar hVISA olarak tanımlanmaktadır (17). MRSA'lar içerisinde VISA suşlarına halen ender olarak rastlanmasına rağmen, hVISA suşlarının görülme sıklığ 1 $\%$ 0,71-65 arasında olmak üzere değişkenlik göstermektedir (17-20).

Stafilokoklarda gözlenen bu direnç gelişimini takiben ilk kez 2002 yılında Michigan'da bir diyaliz hastasında VRSA izolatı tanımlanmıştır. Bugüne kadar, tüm dünyada VRSA enfeksiyonunun görüldüğü 11 olgu mevcuttur. Bunlardan dokuzu ABD'den (Michigan 7, Pennsylvania 1, New York 1 olgu), ikisi ise İran ve Hindistan'dan bildirilmiştir. Bu olguların hepsinde PCR ile vanA geni gösterilmiştir (21).

2006 yılına kadar S. aureus için vankomisin direnç sınır değerleri, $\leq 4 \mu \mathrm{g} / \mathrm{ml}$ duyarlı, $8-16 \mu \mathrm{g} / \mathrm{ml}$ orta duyarlı ve $\geq$ $32 \mu \mathrm{g} / \mathrm{ml}$ dirençli olarak kabul edilmiştir. 2006 yılında ise CLSI, in vitro duyarlılık sonuçları ile elde edilen klinik sonuçlar arasındaki korelasyonu arttırabilmek amacıyla $S$. aureus için belirlenmiş olan vankomisin MIKK direnç sınır değerlerini düşürmüştür. Sonuç olarak günümüzde yeni direnç sınır değerlerine göre, MIK $\leq 2 \mu \mathrm{g} / \mathrm{ml}$ olan izolatlar duyarlı, 4-8 $\mu \mathrm{g} / \mathrm{ml}$ olan izolatlar VISA ve $\geq 16$ $\mu \mathrm{g} / \mathrm{ml}$ olanlar VRSA olarak kabul edilmektedir (22). Dolayısıyla daha önceden hVISA olarak tanımlanmış olan izolatlardan bazıları, yeni belirlenmiş olan değerlere göre VISA olarak kabul edilmektedir. Benzer olarak EUCAST, 2009 yılında VISA tanımını tamamen kaldırarak, vankomisin MİK değeri $\geq 4 \mu \mathrm{g} / \mathrm{ml}$ olan tüm $S$. aureus izolatlarını vankomisine dirençli olarak kabul etmiştir. Yapılan tüm bu değişikliklere rağmen ne yazık ki vankomisin MIK değeri $2 \mu \mathrm{g} / \mathrm{ml}$ olan $S$. aureus izolatları ile vankomisin tedavisinde başarısızlıklar görülmeye devam etmiştir. $\mathrm{Bu}$ durum özellikle bakteriyemi ya da pnömoni gibi ciddi MRSA enfeksiyonlarında saptanmıştır (23).

hVISA izolatları standart duyarlılı testleriyle tanımlanamamaktadır. Bugüne kadar hVISA izolatlarının tanımlamasında birçok yöntem denenmiştir. Bunların arasında Hiramatsu'nun E-test makrometodu ve PAPAUC yöntemi sayılabilir (17). PAP-AUC yöntemi günümüzde hVISA izolatlarının saptanmasında altın standart olarak kabul edilmekle birlikte, rutinde uygulanması zor, pahalı ve zahmetli bir yöntemdir. E-test makrometodu ise hVISA izolatlarının saptanmasıly ilgili yapılan birçok çalışmada diğer yöntemlerle karşılaştırıldığında, PAP-AUC yöntemine daha yakın duyarlılık ve özgüllük değerlerine sahip bir yöntem olarak bulunmuştur $(17,20,24)$. 
Türkiye'de MRSA izolatlarında hVISA varlığını araştıran ilk çalışmayı 2005 yılında Sancak ve arkadaşları yapmışlardır (20). Bu çalışmada 256 MRSA izolatından 46's1 (\%18) PAP-AUC yöntemiyle hVISA olarak tespit edilmiştir. Kuşçu ve arkadaşları, 148 metisiline dirençli stafilokok kökeninde, hVISA araştırmışlar ve 107 MRSA içerisinde bir adet $(\% 0,9)$ hVISA izolat tespit etmişlerdir (9). Mirza ve arkadaşları, ilk kez pediyatrik popülasyondan izole edilen MRSA izolatlarında, PAPAUC çalışmışlar ve \%21,3'ünün hVISA olduğunu tespit etmişlerdir (25). Korkut Tunç ve arkadaşları (26) 52 adet MRSA suşundan, popülasyon analiz profili sonucuna göre dokuzunda $(\% 17,30)$ hVISA saptamışlardır. Yunanistan'da Souli ve arkadaşları (27), 175 izolatta altı adet $(\% 3,4)$ hVISA tespit etmişlerdir. Khatib ve arkadaşları (28) 371 MRSA izolatı arasından \%1,6'sında $(n=6)$ VISA, \%8,1'inde $(n=30)$ hVISA tespit etmişlerdir. Pitz ve arkadaşlarının (29) yapmış olduğu çalışmada 147 MRSA izolatında hVISA sıklığ $1 \% 1,2(n=2)$ olarak tespit edilmiştir. Yapılan çalışmalarda saptanan prevalans oranları \%0,9 ile \%21,3 arasında değişmektedir. Elde edilen farklı sonuçların başlıca nedeni, kullanılan yöntemlerin (Mikrodilüsyon, Makrodilüsyon, PAP-AUC gibi) ve alınan örnek türlerinin (tüm stafillokoklar ya da sadece MRSA'lar gibi) farklı olmasına bağlanmıştır. Bugün için kabul edilen altın standart PAP yöntemidir; ancak oldukça zahmetli ve zaman alıcıdır. Metisiline direnç saptanan bütün stafilokoklarda, PAP-AUC uygulanması rutin laboratuvar şartlarında mümkün olmayacağından hVISA şüpheli izolatların tespit edilmesi için farklı tarama yöntemleri geliştirilmiştir. Bunlar arasında en çok kullanılan yöntemler, standart E test, makro E test, vankomisin içeren agar tarama yöntemleridir. Fakat yapılan çalışmalarda farklı sonuçlar bildirilmesi nedeniyle yöntemler rutin kullanım için henüz standardize edilmemiş; hangi yöntemin güvenle kullanılabileceğine dair bir konsensüs sağlanmamıştır (9,30). Bizim çalışmamızda da, kullanmış olduğumuz 6 $\mu \mathrm{g} / \mathrm{ml}$ vankomisin içeren tarama plaklarında iki suşta üreme saptanmış olup bunların doğrulama testleriyle (E test, makro E test, PAP AUC ) aslinda vankomisine duyarlı olduğu görülmüştür. Vankomisin tarama agarın ilk basamakta vankomisin direnci saptamada kolay ve maliyet etkin bir yöntem olduğu görülmüştür. Agar tarama testinde saptanmış dirençli suşların doğrulanmasında E test ve PAP yöntemlerinin mutlaka yapılması gerektiği kanısına varılmıştır.

Çoklu antibiyotik direnci gösteren MRSA'ların etken olduğu enfeksiyonlarda tek tedavi seçeneği olarak çoğu kez glikopeptid antibiyotikler kullanılmaktadır. Bu antibiyotiklerin yoğun bir biçimde kullanılması, stafilokoklarda glikopeptidlere karşı hassasiyet azalmasına ve direnç gelişmesine sebep olmuştur. Stafilokoklarda azalmış glikopeptid direncinin taranması ve doğrulanması için tüm dünyada kabul görmüş bir yöntem olmamasına rağmen vankomisin tarama agar, standart E test, makro E test ve altın standart olarak kabul edilen PAP-AUC oranının hesaplanması önerilmektedir. Çalışmamızda da vankomisinli agar tarama besiyerinde üreyen S. aureus'ların standart E-test, makro E test ile MİK değerlerinin duyarlı sınır aralıklarında olduğu gösterildi. En sonunda altın standart olarak kabul edilen PAP-AUC yönteminin kullanılmasıyla da vankomisine karşı azalmış hassasiyet ya da dirence rastlanmadı.

Sonuç olarak bu seçkin antibiyotiğin özenli kullanılmasının, gerek tedavi öncesi, gerekse tedavi sırasında hastaların mikrobiyolojik yönden yakın izlemi önemli ve gereklidir.

Finansal Destek: $\mathrm{Bu}$ çalışma Düzce Üniversitesi Bilimsel Araştırma Projeleri Fonu tarafindan desteklenmiştir. Proje No: 2012.04.HD.066

\section{KAYNAKLAR}

1. Culos KA, Cannon JP, Grim SA. Alternative agents to vancomycin for the treatment of methicillin-resistant Staphylococcus aureus infections. AmJ Ther. 2013; 20(2): 200-12.

2. Ippolito G, Leone S, Lauria FN, Nicastri E, Wenzel RP. Methicillin-resistant Staphylococcus aureus: the superbug. IntJ Infect Dis. 2010; 14(14): 7-11.

3. Sancak B. Staphylococcus aureus ve antibiyotik direnci. Mikrobiyol Bul. 2011; 45(3): 565-76.

4. Kırca F. Staphylococcus aureus suşlarında metisilin direnci tanısında kullanılan bazı fenotipik yöntemlerin karşılaştırılması [Uzmanlık tezi]. Ankara: Gazi Üniversitesi Tıp Fakültesi; 2008.

5. Swenson JM, Lonsway D, McAllister S, Thompson A, Jevitt L, Zhu W, et al. Detection of mecAmediated resistance using reference and commercial testing methods in a collection of Staphylococcus aureus expressing borderline oxacillin MICs. Diagn Microbiol Infect Dis. 2007; 58: 3-39.

6. Azarkan A. Yoğun bakım ünitelerinde yatan hastalarda metisilin rezistan Staphylococcus aureus'un hizlı test (moleküler yöntem) ile araştırılması [Uzmanlık tezi]. Diyarbakır: Dicle Üniversitesi Tıp Fakültesi; 2011.

7. Sancak B. Staphylococcus aureus'ta metisilin ve vankomisin direnci. Hacettepe Tip Dergisi. 2007; 38: 127-34.

8. Brown DF, Edwards DI, Hawkey PM, Morrison D, Ridgway GL, Towner KJ, et al. Guidelines for the laboratory diagnosis and susceptibility testing of methicillin-resistant Staphylococcus aureus (MRSA). J Antimicrob Chemother. 2005; 56(6): 1000-18.

9. Kuşçu F, Öztürk D, Gürbüz Y, Tütüncü E, Şencan İ, Gül S. Metisiline dirençli stafilokoklarda azalmış vankomisin duyarlılı̆̆ının araştırılması. Mikrobiyol Bul. 2011; 45(2): 248-57.

10. Çetinkaya Y. Metisilin dirençli Staphylococcus aureus enfeksiyonlarının epidemiyolojisi ve kontrolü. Hastane İnfeksiyonları Derg. 2000; 4: 205-17.

11. Cosgrove SE, Qi Y, Kaye KS, Harbarth S, Karchmer AW, Carmeli Y. The impact of methicillin resistance in Staphylococcus aureus bacteremia on patient outcomes: mortality, length of stay, and hospital charges. Infect Control Hosp Epidemiol. 2005; 26(2): 166-74.

12. National Nosocomial Infections Surveillance (NNIS) System Report, data summary from January through 1992 June 2004, issued October 2004. Am J Infect Control. 2004; 32(8): 470-85.

13. Derbentli Ş. Stafilokoklarda antibiyotik direnci, 20032004 Türkiye haritası. ANKEM Derg. 2005; 19(Ek 2): 54-60. 
14. Refik Saydam Hıfzıssıhha Merkezi Başkanlığı'nca yayınlanan Ulusal Hastane Enfeksiyonları Sürveyans Ağı (UHESA) Raporu Özet Veri Kitapçığı. [Son güncelleme tarihi: 6 Mayıs 2017; Erişim tarihi: 19 Temmuz 2018]. Erişim adresi: www.rshm.gov.tr/ enfeksiyon/ dosya/lab.doc.

15. Shorr AF. Epidemiology of staphylococcal resistance. Clin Infect Dis. 2007; 45(3): 171-6.

16. Hiramatsu K, Hanaki H, Ino T, Yabuta K, Oguri T, Tenover FC. Methicillin-resistant Staphylococcus aureus clinical strain with reduced vancomycin susceptibility. J Antimicrob Chemother. 1997; 40(1): 135-6.

17. Howden BP, Davies JK, Johnson PD, Stinear TP, Grayson ML. Reduced vancomycin susceptibility in Staphylococcus aureus, including vancomycinintermediate and heterogeneous vancomycinintermediate strains: resistance mechanisms, laboratory detection and clinic alimplications. Clin Microbiol Rev. 2010; 23(1): 99-139.

18. Van Hal SJ, Paterson DL. Systematic review and meta-analysis of the significance of heterogeneous vancomycin-intermediate Staphylococcus aureus isolates. Antimicrob Agents Chemother. 2011; 55(1): 405-10.

19. Bell JM, Walters LJ, Turnidge JD, Jones RN. hVISAs are common among vancomycin susceptible methicillin-resistant Staphylococcus aureus (MRSA). Program and abstracts of the 46th Annual Meeting of the Interscience Conference on Antimicrobial Agents and Chemotherapy (ICAAC); 2006 September; San Francisco, CA. Washington: American Society for Microbiology; 2006. p. 1160.

20. Sancak B, Ercis S, Menemenlioglu D, Colakoglu S, Hasçelik G. Methicillin-resistant Staphylococcus aureus heterogeneously resistant to vancomycin in a Turkish university hospital. J Antimicrob Chemother. 2005; 56(3): 519-23.

21. Gould IM. Clinical activity of anti-Gram-positive agents against methicillin-resistant Staphylococcus aureus. J Antimicrob Chemother. 2011; 66(14): 17-21.

22. Hardy KJ, Hawkey PM, Gao F. Oppenheim BA. Methicillin resistant Staphylococcus aureus in the critically ill. Br J Anaesth. 2004; 92(1): 121-30.

23. Nannini E, Murray BE, Arias CA. Resistance or decreased susceptibility to glycopeptides, daptomycin, and linezolid in methicillin-resistant Staphylococcus aureus. Curr Opin Pharmacol. 2010; 10(5): 516-21.

24. Walsh TR, Bolmström A, Qwarnström A, Ho P, Wootton M, Howe RA, et al. Evaluation of current methods for detection of staphylococci with reduced susceptibility to glycopeptides. J Clin Microbiol. 2001; 39(7): 2439-44.

25. Mirza HC, Sancak B, Gur D. The prevalence of vancomycin-intermediate Staphylococcus aureus and Heterogeneous VISA among methicillin-resistant strains isolated from pediatric population in a Turkish university hospital. Microbial Drug Resistance. 2015; 21(5): 537-44.

26. Korkut Tunç E, Kuzucu Ç, Otlu B. Metisiline dirençli Staphylococcus aureus suşlarında vankomisine karş1 azalmış duyarlılığın araştırılması. Türk Mikrobiyol
Cem Derg. 2017; 47(1): 39-46.

27. Souli M, Karaiskos I, Galani L, Maraki S, Perivolioti E, Argyropoulou A, et al. Nationwide surveillance of resistance rates of Staphylococcus aureus clinical isolates from Greek hospitals, 2012-2013. Infectious Diseases. 2016; 48(4): 287-92.

28. Khatib R, Jose J, Musta A, Sharma M, Fakih MG, Johnson LB, et al. Relevance of vancomycinintermediate susceptibility and heteroresistance in methicillin-resistant Staphylococcus aureus bacteraemia. Journal of Antimicrobial Chemotherapy. 2011; 66(7): 1594-9.

29. Pitz AM, Yu F, Hermsen ED, Rupp ME, Fey PD, Olsen KM. Vancomycin susceptibility trends and prevalence of heterogeneous vancomycinintermediate Staphylococcus aureus in clinical methicillin-resistant $S$. aureus isolates. Journal of Clinical Microbiology. 2011; 49(1): 269-74.

30. Wootton M, MacGowan AP, Walsh TR, Howe RA. A multicenter study evaluating the current strategies for isolating Staphylococcus aureus strains with reduced susceptibility to glycopeptides. Journal of Clinical Microbiology. 2007; 45(2): 329-32. 